\title{
Lithuanian school libraries today: Problems and perspectives
}

\author{
Irena Kryzanauskiene \\ School library manager \\ Vilnius Antakalnis secondary school \\ Chairman of School department \\ Lithuania Librarian Association \\ Lithuania
}

\begin{abstract}
The situation of Lithuanian school libraries and the status of librarians are ambiguous, because libraries are financed by Ministry of Education and Science, but legal acts, except the laws, are organized by Ministry of Culture. School libraries are very important among other libraries in Lithuania according to the latest statistic data of Lithuania. In 2000 the school libraries computerization started and in 2004 they were instilled with a simplified version of the Lithuanian Integrated Library Information System (LILIS) - so called Information System of School Libraries (ISSL). The questioning of school librarians was done in 2006-2007 years. Analysis of questionnaires showed that there are some problems in activity of school libraries. The Standard of Digital Literacy of School Librarians (SDLSL) has contradictory estimations. It contains extremely high requirements for school librarians in the sphere of ICT use. Lithuania school librarians do not have a professional association. Members of IASL in Lithuania are only separate school librarians. The methodical help to school libraries should be given by the Municipality public libraries but the help is given not very often. In some towns more active and experienced librarians organize methodical groups, give seminars for those, who are less experienced. School librarians take part in different state actions. Year 2008 is announced to be Reading year in Lithuania. Reading year is stage of Reading Promotion Program confirmed by the Government.
\end{abstract}

Lithuanian libraries, Reading promotion, Reading Year

\section{The legal situation of Lithuania school libraries and the documents, which regulate the activities of school librarians}

Lithuania is one of the three independent Baltic States and belongs to the region, which is referred to as Central and Eastern Europe.

The legal status of school librarians in Lithuania is ambiguous, because libraries that are established by the state or of the Municipalities are financed by the Ministry of Education and Science, but legal acts, except the laws, that school libraries have to use, are organized by the Ministry of Culture. The Ministry of Culture, which along with the Library Council determines the library development strategy: management and financing of library programs and research subjects; co-ordination of the activity of Lithuanian libraries are supervising adherence to the Law on Libraries and other documents regulating library activity.

The Ministry of Education defines their specific requirements for school libraries but I am going to talk about them later in greater detail analyzing the following documents and the role of library at school. Only three documents are prepared by the Ministry of Education and Science: „School Library Conception“(2001) and „Standard of Digital Literacy of School Librarians “(further - Standard) (2002) and „Recommendation for the description of librarians' duties" (2005).

Two first documents have not been fully realized. The realization plan for the first document (Conception) has remained only an intention. And the contradictions of the realization 
of the second document (Standard) will be presented further. The activity of school libraries, oriented to help the education process is organized by the order of the school headmaster documents: description of librarian's duties, the rules of using school libraries and the completing of the funds of textbooks, the rules of inside work.

The work of libraries is regulated by the highest levels of all common types of legal acts: the international and national acts, rules and regulations. The highest level of legal acts in Lithuanian is the Law of Libraries, by article 12 part 2 says, that school library has to work in the state higher, vocational and comprehensive school, 11 article says that school (except high schools) library is the structural subdivision of this school, the school community is served. Also Labor Code, which is used for all workers and Constitution, which is in force for all citizens.

School librariansare not considered pedagogical workers; therefore the order of improvement of pedagogical skills and certification is not applied to them. The salary is paid without consideration of the librarian's qualification and work experience. Unlike in other Baltic states such as Poland, Latvia or Estonia, where school librarians are considered to be teachers, in Lithuania school librarians do not have the status of teacher. Formally they cannot participate in educational activities though they are considered as a teachers in such documents as ,School Library Conception“(2001) or „Standard of Digital Literacy of School Librarians "(SDLSL) (2002). The "Strategy of Instillation of Information Communication Technology (ICT) in Education of Lithuania" defines a school librarian as a specialist of education too. In spite of everything many of school librarians, according to their education as teachers (about $70 \%$ ), they organize different lessons, for formatting information skills already today, but they cannot-participate in the educational process at all.

SDLSL can also have contradictory estimations. It contains extremely high requirements for school librarians in the sphere of ICT use. Now we are going to discuss the main regulations of this document and its evaluation.

\subsection{The Standard of Digital Literacy of School Librarians of Lithuania (SDLSL)}

\subsubsection{General description:}

The Standard of Digital Literacy of School Librarians decides upon the competences that school librarian should have in order to use digital recourses for developing students' information skills and serving readers.

1.1.2. The school librarian must:

- Know the national conception of the development of information society

- Know the role of the school library in the formation of information society in Lithuania.

- Understand social and ethic specifics of using ICT for education.

- Know (and be able to apply) strategies and techniques of integrating ICT into education process and library work.

- Have the qualification, described in the teachers' digital literacy standard.

1.1.3. The Standard is based on:

- The Strategy of Instillation of information-communication technology in education in Lithuania, where the school librarian is defined as an educational specialist. The conception of using information and communication technology in education; the conception of libraries

- The Standard of Digital Literacy of Teachers' is supplemented with the requirements for librarians. 
- Curriculum of European Computer Driving License - ECDL

The term "digital literacy" is used in the wide sense of meaning. It means not only being able to use the computer but also the ability of using ICT in searching for information, storing and processing (handling) it.

According to the Standard every librarian should have 80 hours ( 2 credits) of education in computer science and IT; $40 \%$ of the time should be spent on individual work, $1 / 3$ of the topics - on the technological part.

\subsubsection{Calls for the competence}

The object of the Standard is the competence of the librarian in the field of information and communication technology.

1. The school librarian must be able:

- To use software necessary for library work;

- To use digital recourses and data base;

- To use qualified Internet service;

- To use electronic publications (books, magazines, dictionaries, encyclopedia, etc.);

- To use ICT in every day work: create Internet websites and other computer documents;

- To develop information culture in the local (school) community.

2. Improving professional skills and sharing experience, a librarian must know:

- The possibilities of professional development using ICT;

- The strategy of modernizing libraries, understand electronic and virtual library;

- The importance of Internet, information resources of the state, information systems of the state. Understand the forms and standards of bibliographic information creation and spread on the Internet.

- The using peculiarities of electronic and Internet issues.

- UNIMARC format and how to use it describing documents.

- Legal aspects on information and data protection.

In my opinion the Standard of Digital Literacy of School Librarians was approved by the Ministry of Education and Science in 2002, but still the competence of many school librarians does not satisfy the requirements of the Standard. The reasons are:

1. They are not taught how to use databases, or they don't have them at all.

2. The Educational part of the Standard is impossible to implement because librarians are not teachers and many of them cannot participate in teaching.

3. The requirement of 80 hours of compulsory work is not in action, though 6 years have passed since the Standard was confirmed.

4. The requirement for librarians to have the qualification, described in teachers' digital Literacy Standard is baseless as librariansare not regarded as teachers.

\subsection{Description of Duties of Librarians}

Description of Duties of Librarians (further - Duty Description) is the main document directly regulating school librarians' activities. A librarian must do all work defined in the description of duty and he/she can refuse to do what is not mentioned in the Description. This document is very important for the working person (after the Job agreement). The Ministry of Education and Science has certified the Recommendations for the preparation of Duty Description, which help school leaders certify duty descriptions for their school librarians, taking 
into consideration the needs of their school. Further on I am going to analyze this document in greater detail, because I participated in the working group, preparing these Recommendations.

\section{Methodical Recommendations for the description of librarian's duties}

The activity of school library is guided by the following documents:

- Law on Libraries

- Law on Education

- Labor Code of the Republic of Lithuania

- Legal acts of the Government

- Regulations of the Ministry of Education

- The Description of duties of librarians

The school library organizes its work following:

- The Statute of school library

- The rules of library

- The Statute of protections of funds

- The different Standards of librarianship

The main aspects of the school library activities are:

- Collection development

- Provision materials as sources of information

- Planning and analyzing the work of libraries

- The account of funds, processing and making catalogues

The description of duties of librarians should consist of the following parts:

- General Principles

- Requirements for the librarian

- The functions and responsibility of the librarian

- The rights and obligations

\section{General Principles}

It is necessary to state the goals of librarian's work:

1. To participate in the educational process and help to develop students skills in finding information

2. To look for new methods of cooperation with the teachers and students

3. To help students to study on their own using informational surrounding

4. To improve the service of readers and to cooperate with other institutions

5. To instill the Information System of School Libraries (ISSL)

\section{Requirements for the librarian or library manager}

- To apply for the position of a librarian or a library manager can a person who has university or specialized education in librarianship and the qualification of a librarian

- A person should have good computer skills, be able to communicate and cooperate

\section{The functions and responsibility of the librarian}

- To plan, analyze, sum up, evaluate the work of the school library and give accounts to the head of the school

- To make annual account, present it to the head of school and other institutions 
- To compile all necessary recourses for education process

- To fill and take care of all the documentation

- To make the rules for library use

- To organize the funds according to the universal decimal classification(UDK)

- To subscribe, process and store the periodicals

- To participate in the development of students' information skills

- To provide recourses for the classroom teachers and staff

- To teach how to use open funds

- To decide upon the damage done to the library and make to pay for it

- To see that everyone keep order in the library and protect funds

- To make information files on actual topics

- To participate in implementation of the school program

- To participate in the activity of the school Board

- To fulfill duties according to the legal acts and laws

- To be responsible for the reliability of the data and information provided and for the quality and development of funds

- To fulfill duties stated in the contract

\section{The rights and obligations}

The librarian or library manager has the right:

- To get all legal acts and information concerning library work

- To get support and consultations from higher institutions

- To have good working conditions and environment

- To develop qualifications for not less than 5 days a year

- To refuse to do activities which are not in the Job Agreement

- One day a month not to serve consumers but to clean, tidy, disinfect and do other things in the library

- One hour a day devote to preparation and revision of periodicals

The librarian or library manager is obliged:

- To keep to the contract and the description of the duties of the librarian

- To fulfill other duties and obligations according to the Labor Code and other legal acts

\section{The place of school libraries among other Lithuanian libraries and their role in public organizations and at school.}

\subsection{School libraries among other Lithuanian libraries and their role in public organizations.}

School libraries are very important among other libraries in Lithuania according to the latest statistic data of Lithuania. They form more than $43 \%$ of all libraries. $28,5 \%$ of all libraries consumers in our country are the consumers of school libraries. 2007, 67\% of all country's libraries had computers, and the access to the Internet $-59,5 \%$. The computerization of school libraries exceeds the average of the country: $81 \%$ of all schools had computers, and the access to the internet $-74,7 \%$. We should emphasize the fact that only the computerization of universities and colleges is in a better condition than in school libraries. 
School libraries have their representatives in the Library Council of Lithuania, which acting alongside the Ministry of Culture as an expert and consultant, deliberates on the most important issues of library activity, submits proposals to the Ministry of Culture and the Government of the Republic of Lithuania concerning the strategy of library development, library scientific programs and their funding, distributes budget funds allocated for library development, assesses the precision and quality of documents and directions in scientific research and other related activities. The Library Council of Lithuania is a non-governmental organization. Members of IASL in Lithuania are only separate school librarians. Now school library enthusiasts are united by the department of School in the Lithuanian Librarians' Association (LLA). Lithuania school librarians do not have a professional association, because nobody wants to volunteer services. Ten years ago the association was established, but its activity stopped because of the indifference of the most participants. The aims of this association are:

1. To raise the reputation of librarians in Lithuanian society;

2. To represent the social and professional rights of its members;

3. To initiate and provide in-service training of librarians;

4. To petition the Lithuanian government and authorities for better recourses and equipment for libraries;

5. To gain experience in the world practice of librarianship;

6. To ensure the utmost professionalism in its members.

There are about 80 members in School Department of LLA, who talk with state institutions if the librarians have any questions and in this way represent the society of school librarians.

\subsection{The role of library at school.}

School libraries create educational environment in their institutions and they have to take a portion of responsibility for developing information skills. The main aim of the libraries is to satisfy the needs of their users and to improve together with the society's development. We can pick out three phases (stages) of the library development:

- library as a storage of information resources

- library as a service supplier

- library as a participant of the educational process

The other aims are:

$\checkmark$ to support and expand the aims and objectives of the school;

$\checkmark$ to develop children's reading skills, encourage the joy of reading, stimulate learning and using libraries all their lives;

$\checkmark$ to create good conditions to acquire skills in searching information, selecting and using it, to gain experience and develop their imagination

Evaluating and accrediting schools, libraries' activities play an important role. The examination of school libraries seeking to see if they are ready to work as information centers, will be carried out in these aspects:

\section{School library's changes:}

1.1. libraries should be ready for the realization of module and optional subject teaching;

1.2. libraries participation in educational process (realization of educational plans, improving the quality on independent learning, cooperation with teachers);

1.3. development of students and teachers' information skills (teaching how to use a library, computer programs, searching for information, estimating and analyzing it;

1.4. library's participation in projects (at school and outside); 
1.5. available library services (answering the requests using all sources of information, making lists of literature, helping students to choose literature for self- studying, helping teachers searching for the methodic literature of their subjects.

1.6. additional services of the library (copying, searching in the data base, possibility to use personal computers, video and audio equipment, international librarian's subscription (ILS) services.)

2. Modernization of the school library:

2.1. Provision with audio, video, TV, copying techniques;

2.2. Computerization of the library (how many computerized working places are in the library and reading room);

2.3. Possibility to use the Internet (connection with the other educational institutions and libraries);

2.4. Possibility to use e-mail;

2.5. Automation of library work (program ISSL): computer catalogue, completing, reader's registration etc.);

2.6. Magnetic and electronic information medium (videotapes, audiotapes, CD);

2.7. Systematized funds of educational computer programs.

2.8. To ensure access to all virtual sources of information;

2.9. To create virtual surroundings, create and diffuse various documents.

3. Filling in the documents of school library funds and work account:

3.1. Library fund inventory book;

3.2. Library fund general registration book;

3.3. Library work's diary;

3.4. Reader's card if the service is not computerized.

4. School library (workers) staff:

4.1. Number of staff members;

4.2. Education of workers:

4.2.1. librarian's (higher /university, college) education;

4.2.2. teacher's (higher /university, college) education;

4.2.3. another education.

5. Library surrounding:

5.1. Reading room in the library or separate;

5.2. Separate reading rooms for students and teachers (how many of them);

5.3. The working places of librarians are computerized;

5.4. There are about 20 working places for students and teachers;

5.5. Computers are connected to the system, the library is supplied with printers, scanners and $\mathrm{CD}$ recording equipment etc.

6. Regulation of the textbooks fund includes:

6.1. The registration of textbooks;

6.2. Withdrawal of the textbooks;

6.3. Compensation for the lost textbooks;

6.4. Buying textbooks;

6.5. Delivery and collecting of textbooks.

7. Library work analyzing and planning. What educational effect does the library have on school community or on society in general? There are hardly any estimation criteria or any other means to measure it. Various questionnaires are organized, analyzed and conclusions are made 
but not more. School library activities are usually planned for a year (such plan is compulsory). Plans may be general (for example, 5 years) or detailed (for a shorter period) but these are not compulsory.

\section{Lithuanian school libraries 2006-2007 (questionnaire research)}

\section{Questionnaires were edited by: Rita Tadarauskiene}

Presentation was prepared by: Irena Kryzanauskiene

Lithuanian Librarians' Association (School department) applied the Ministry of Education and Science asking to help solve the problems. First of all they decided to analyze the real situation of the libraries in our republic. It was the first research ever carried out. The questioning of school librarians was done in the years 2006-2007. Analysis of the questionnaires showed that there are some problems in activity of school libraries.1713 questionnaires were received and analyzed. 


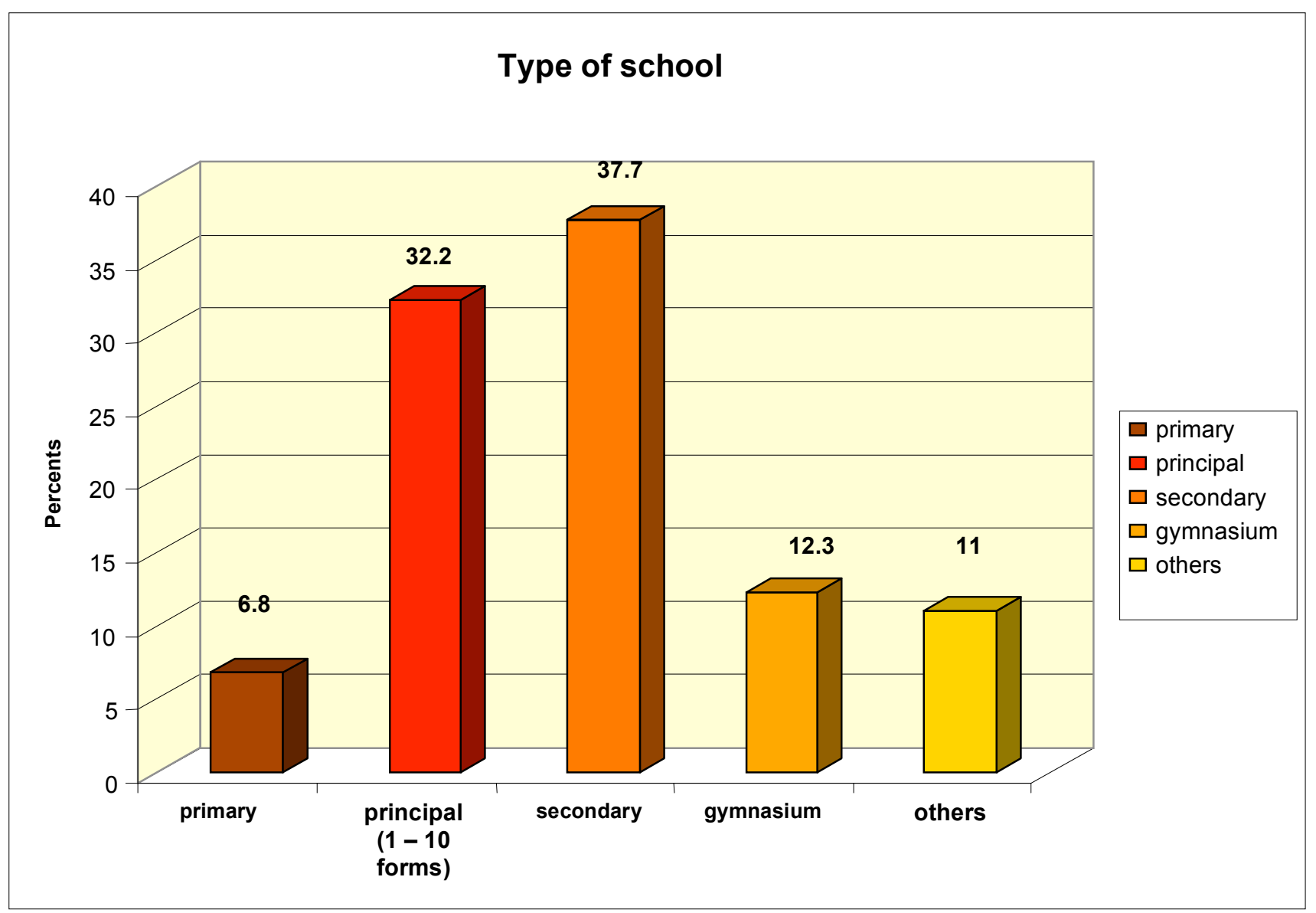




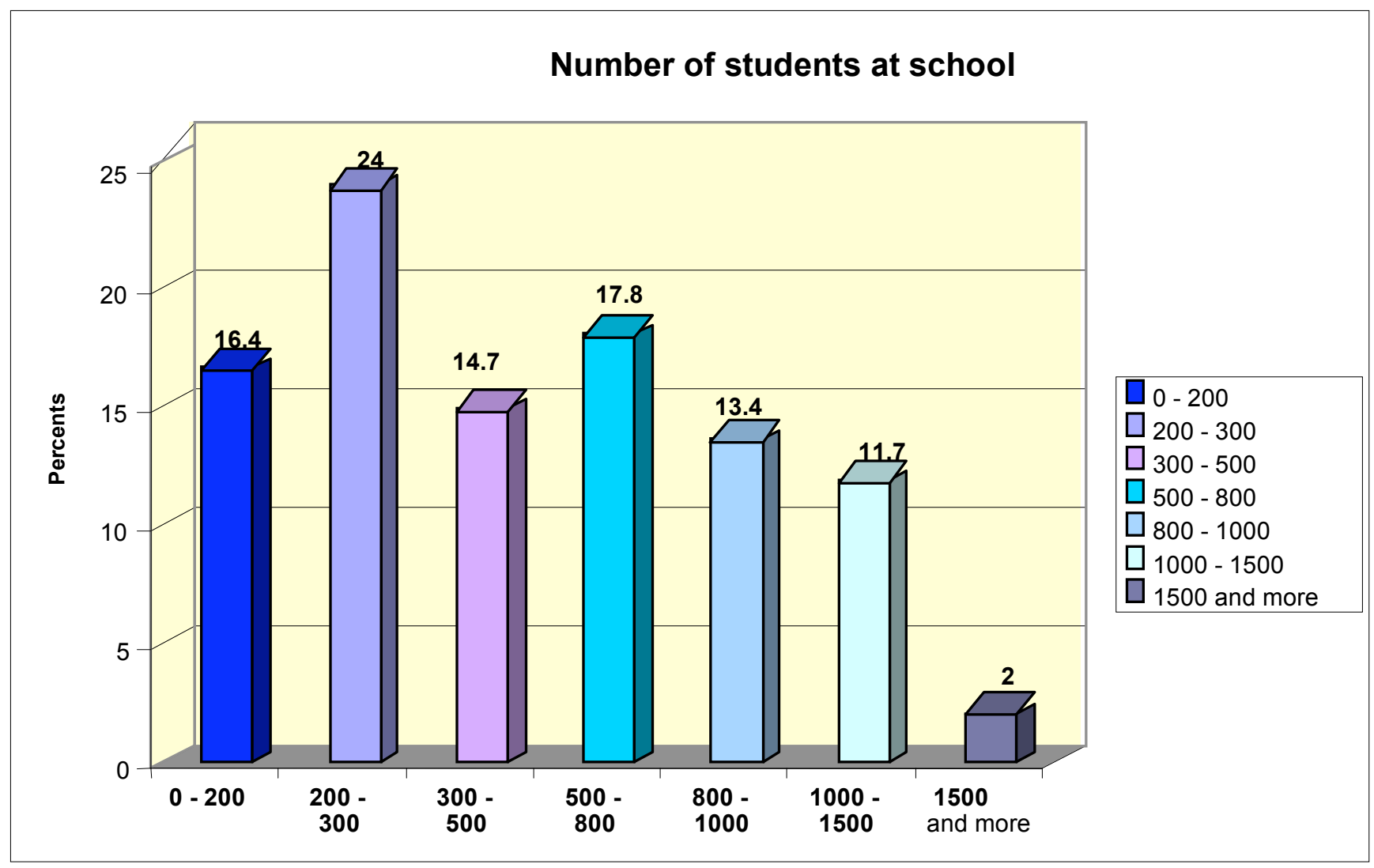




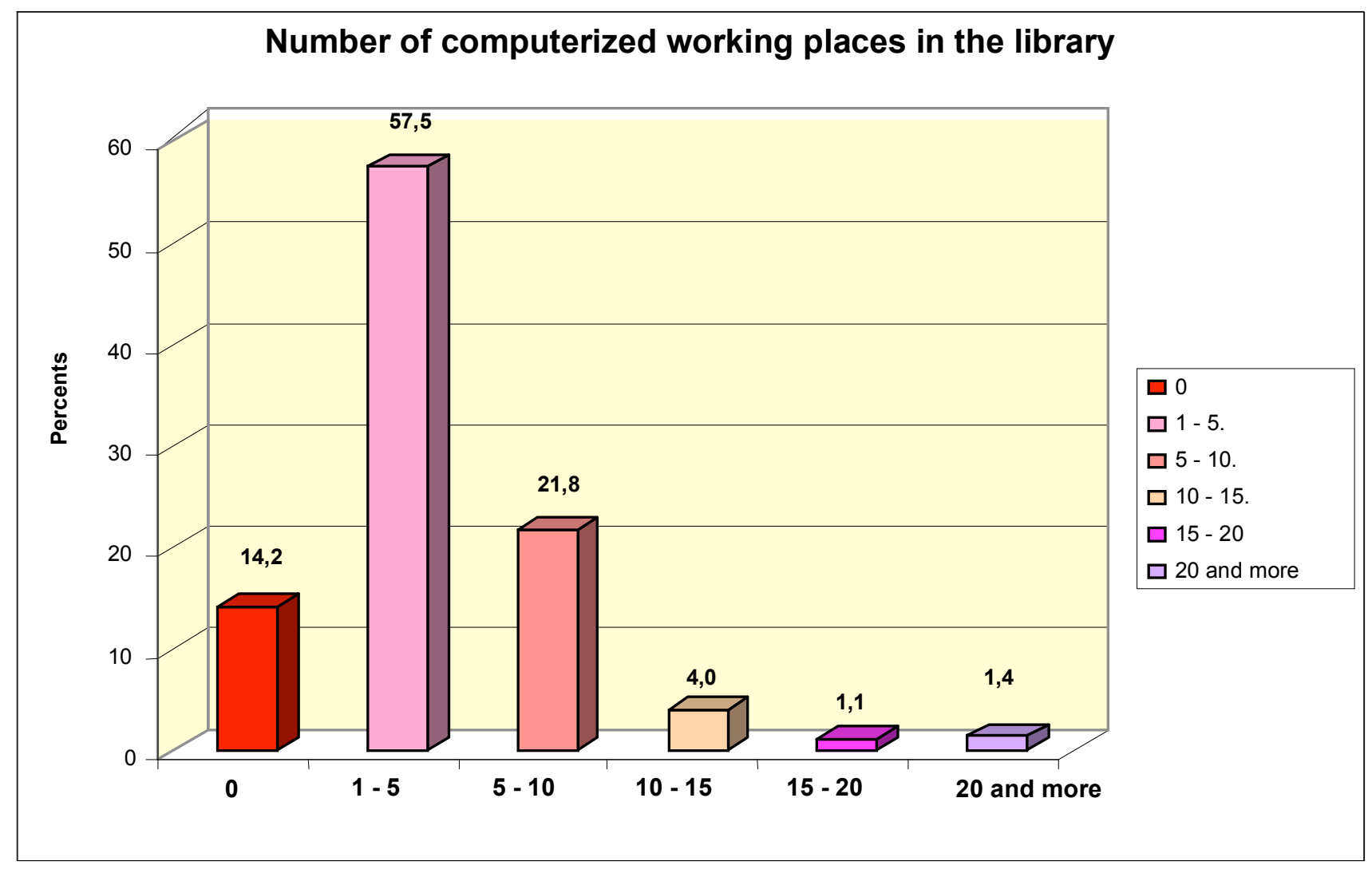




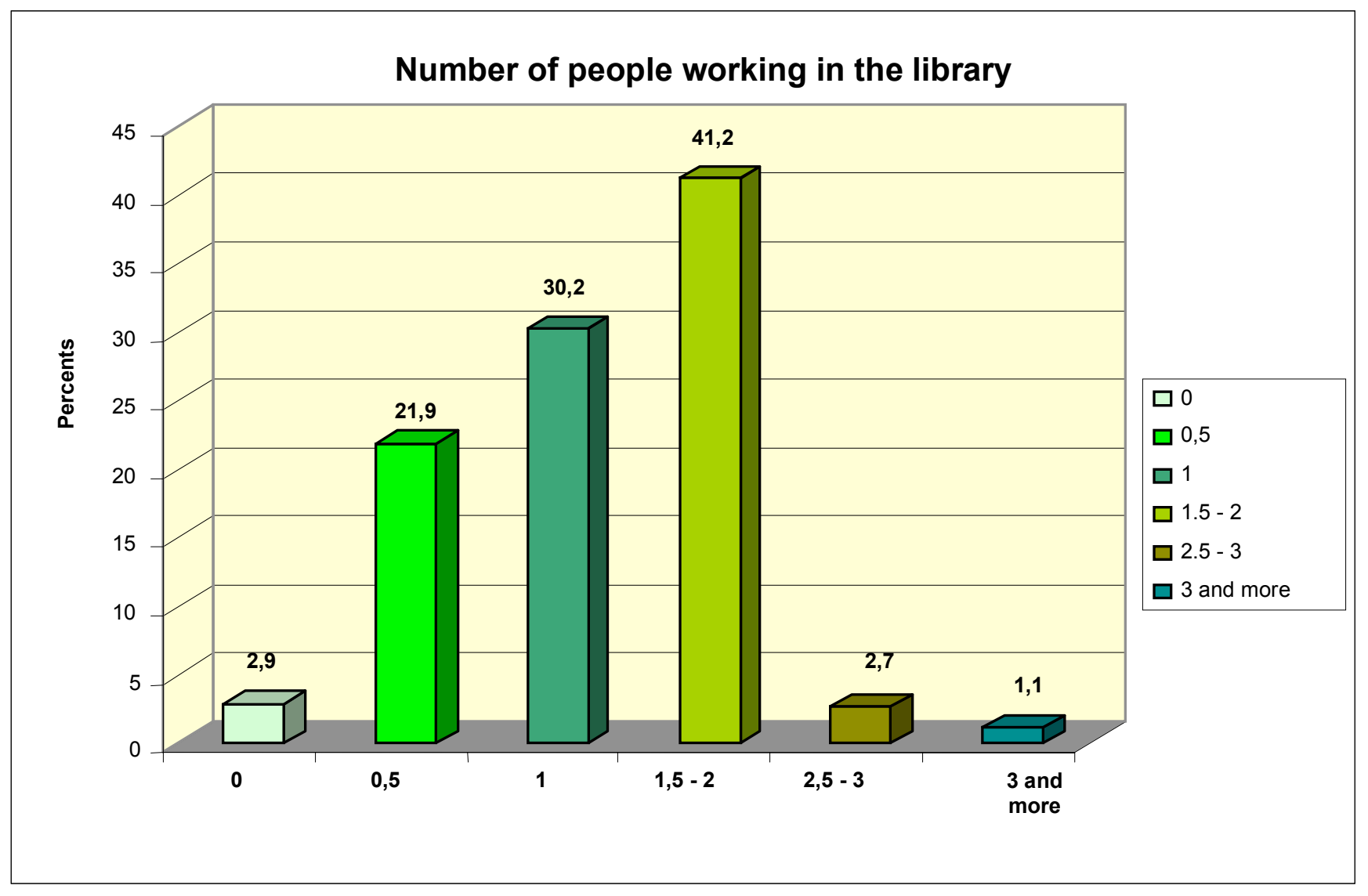




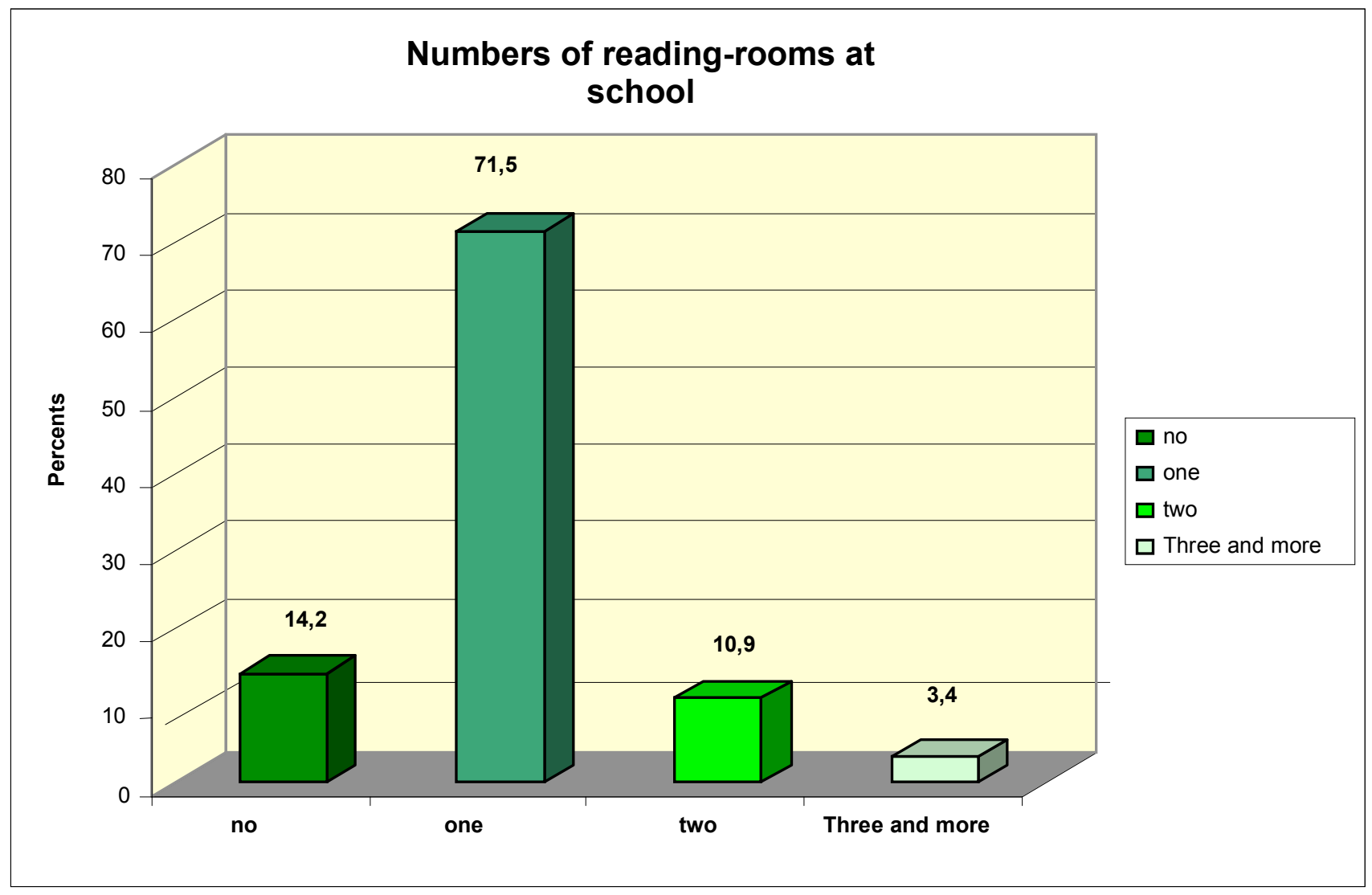




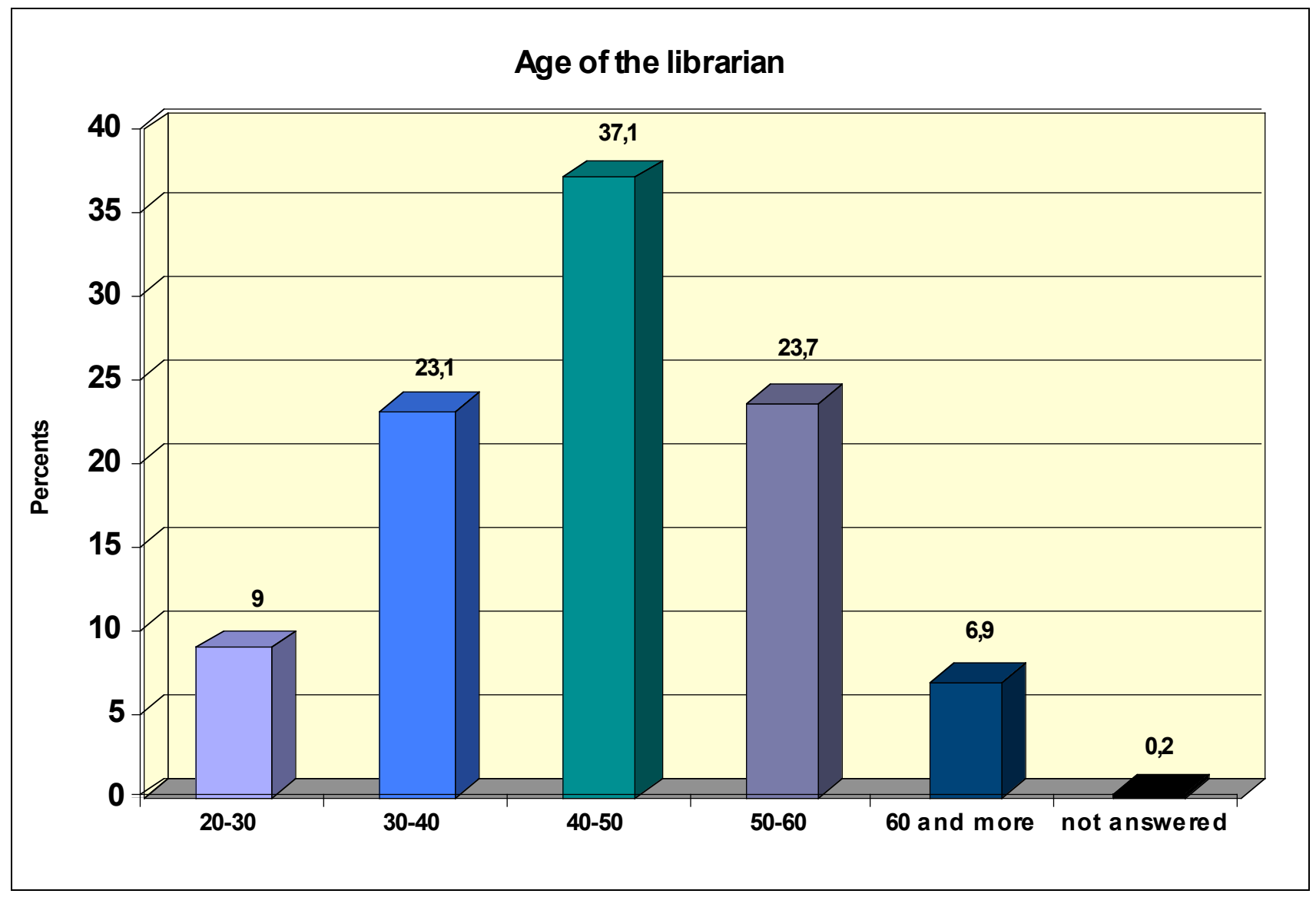




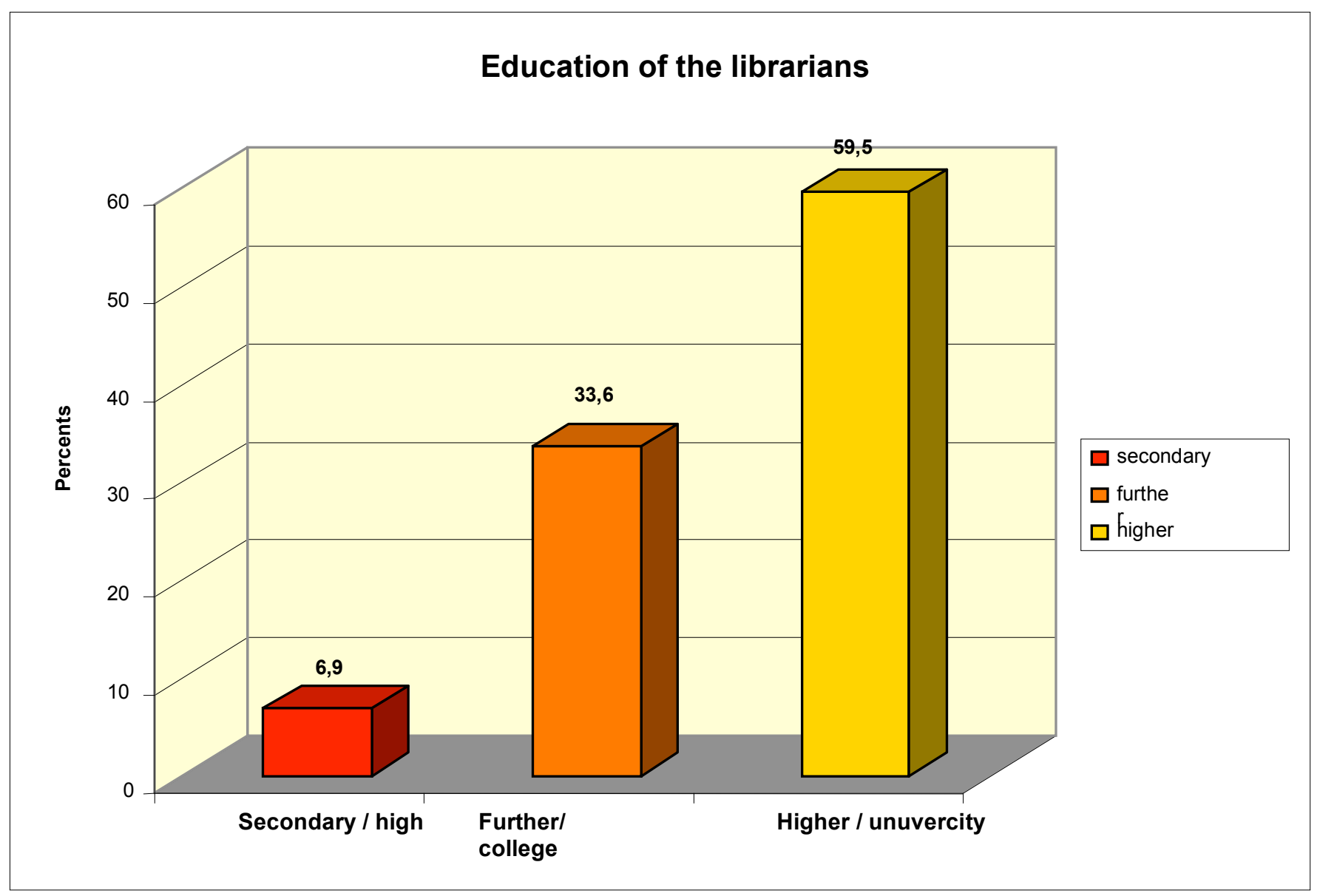




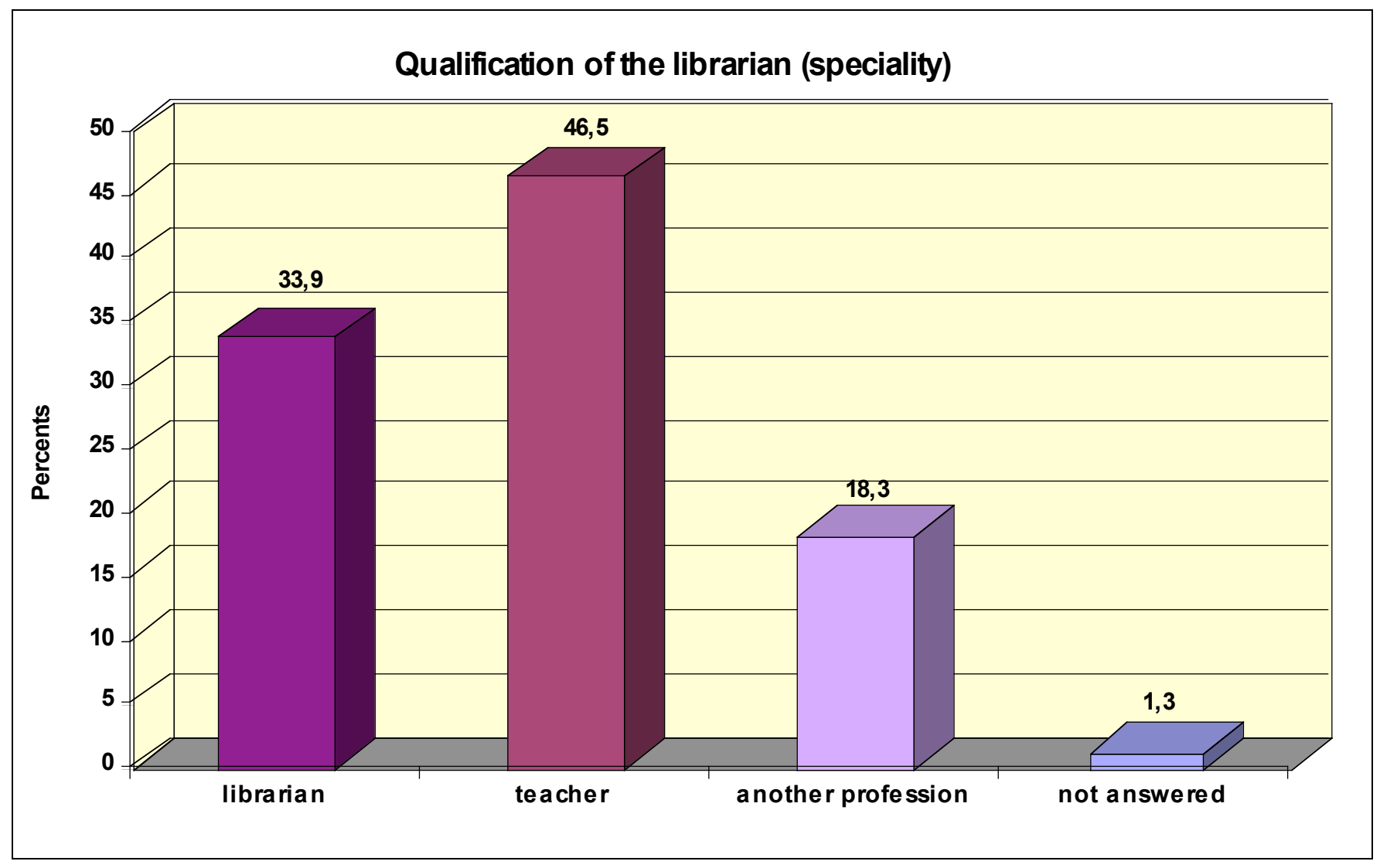




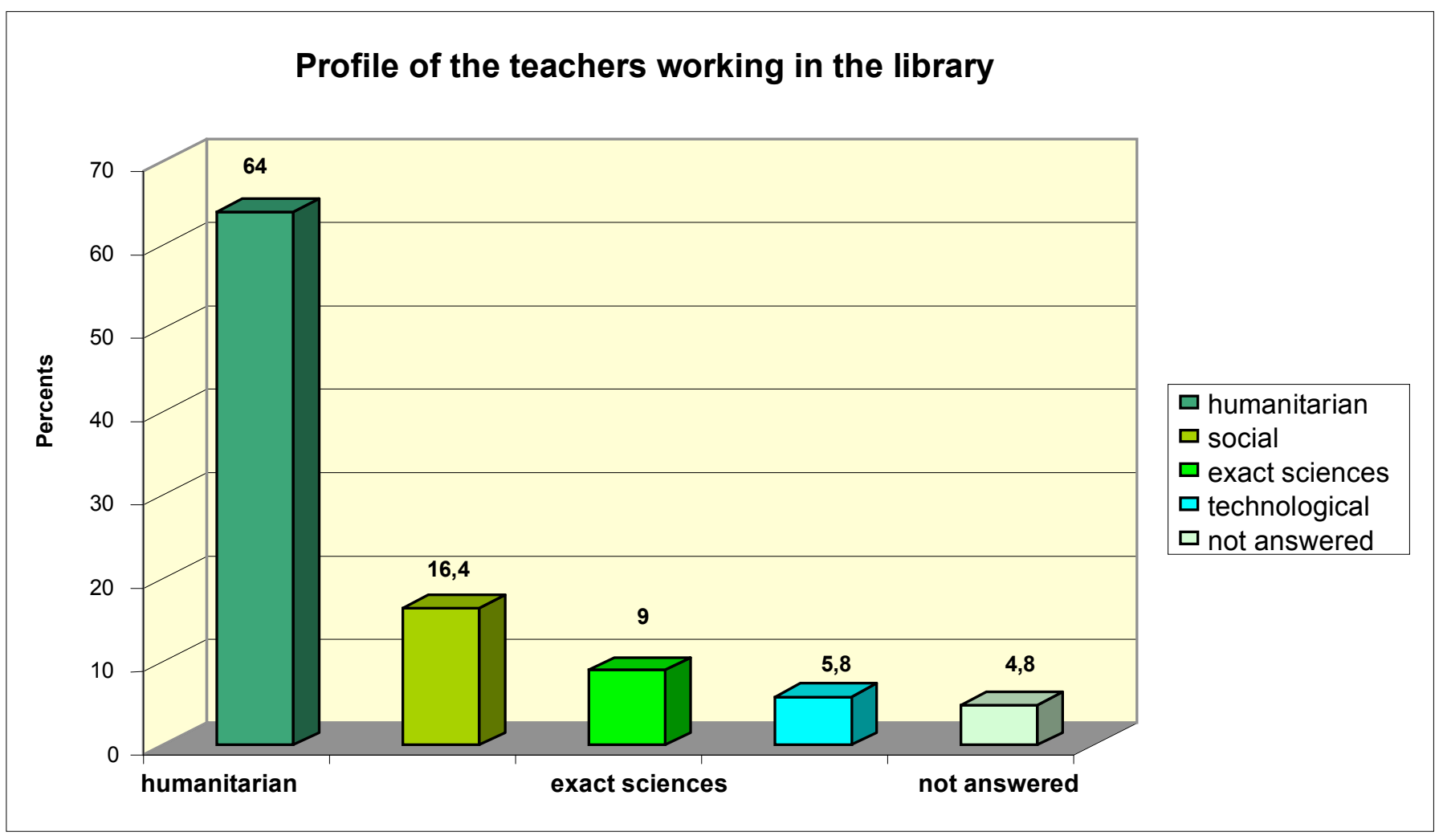




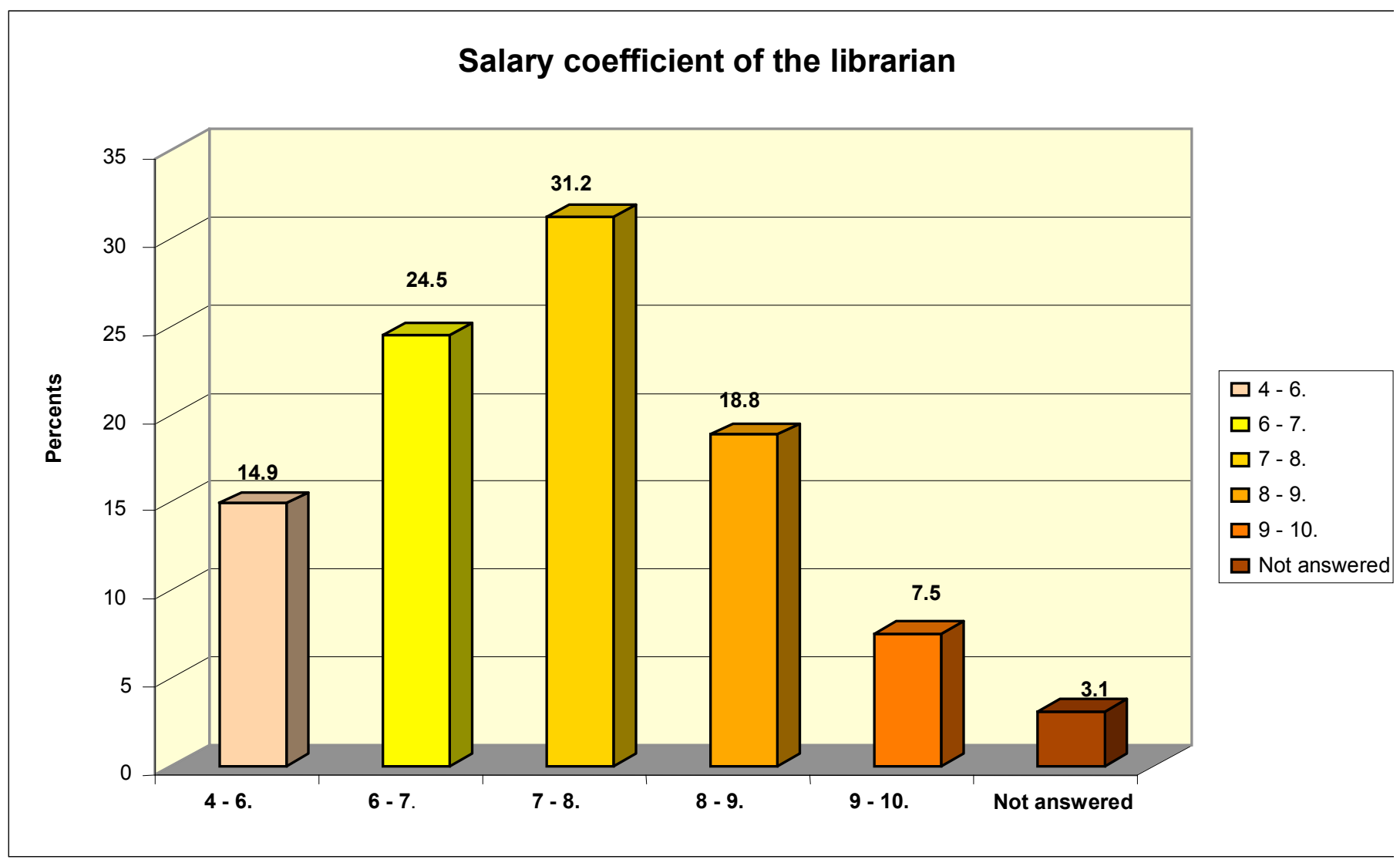




\section{Should librarians post be equal to teachers?}

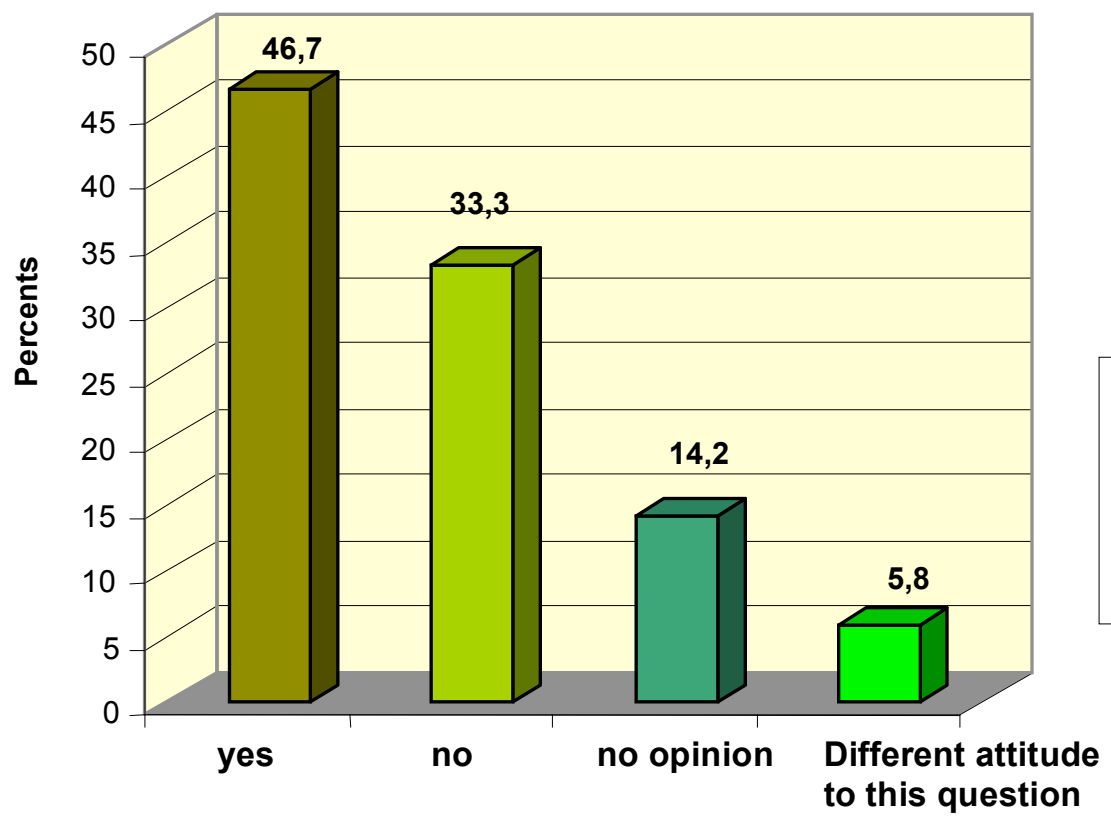




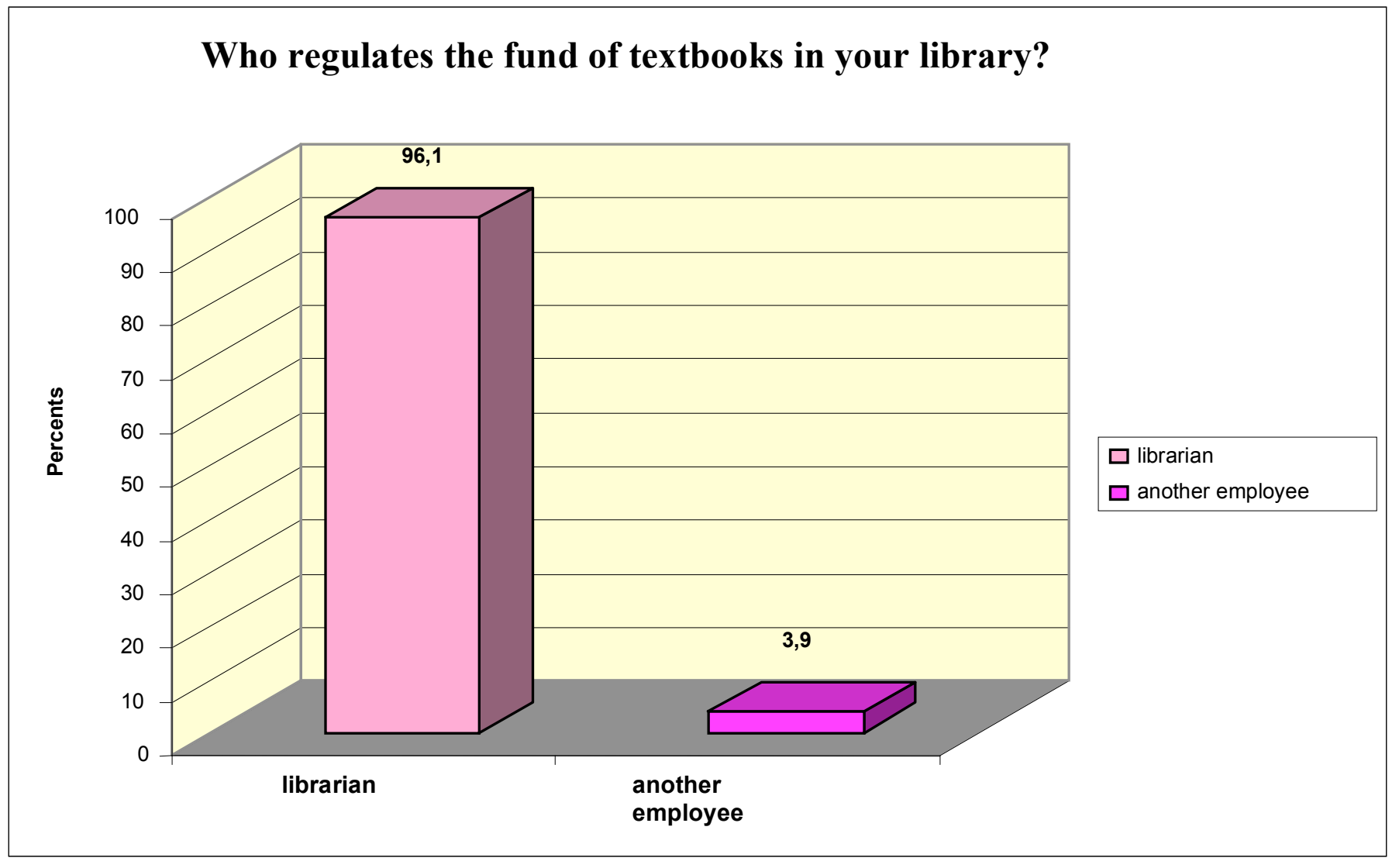




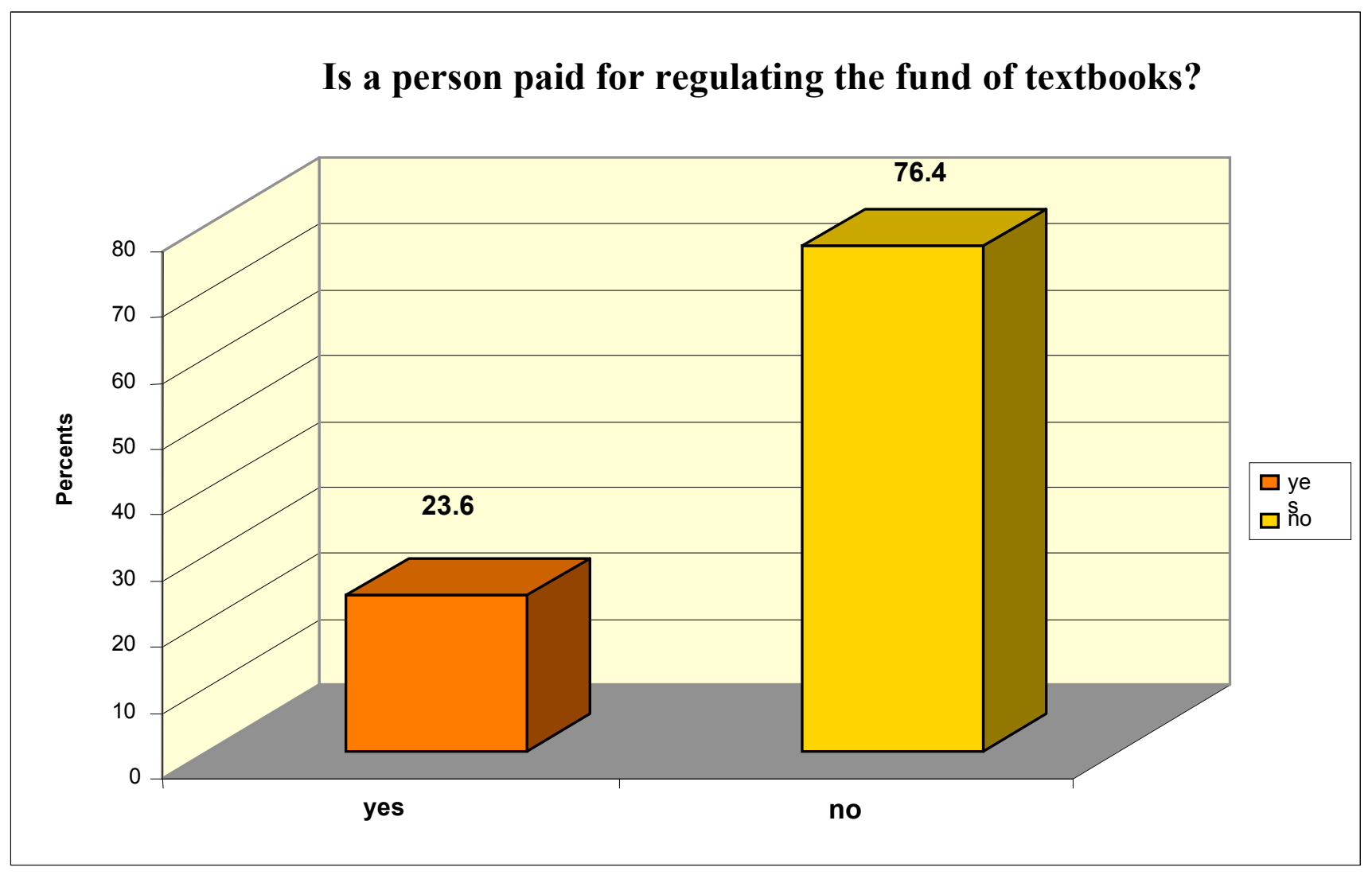




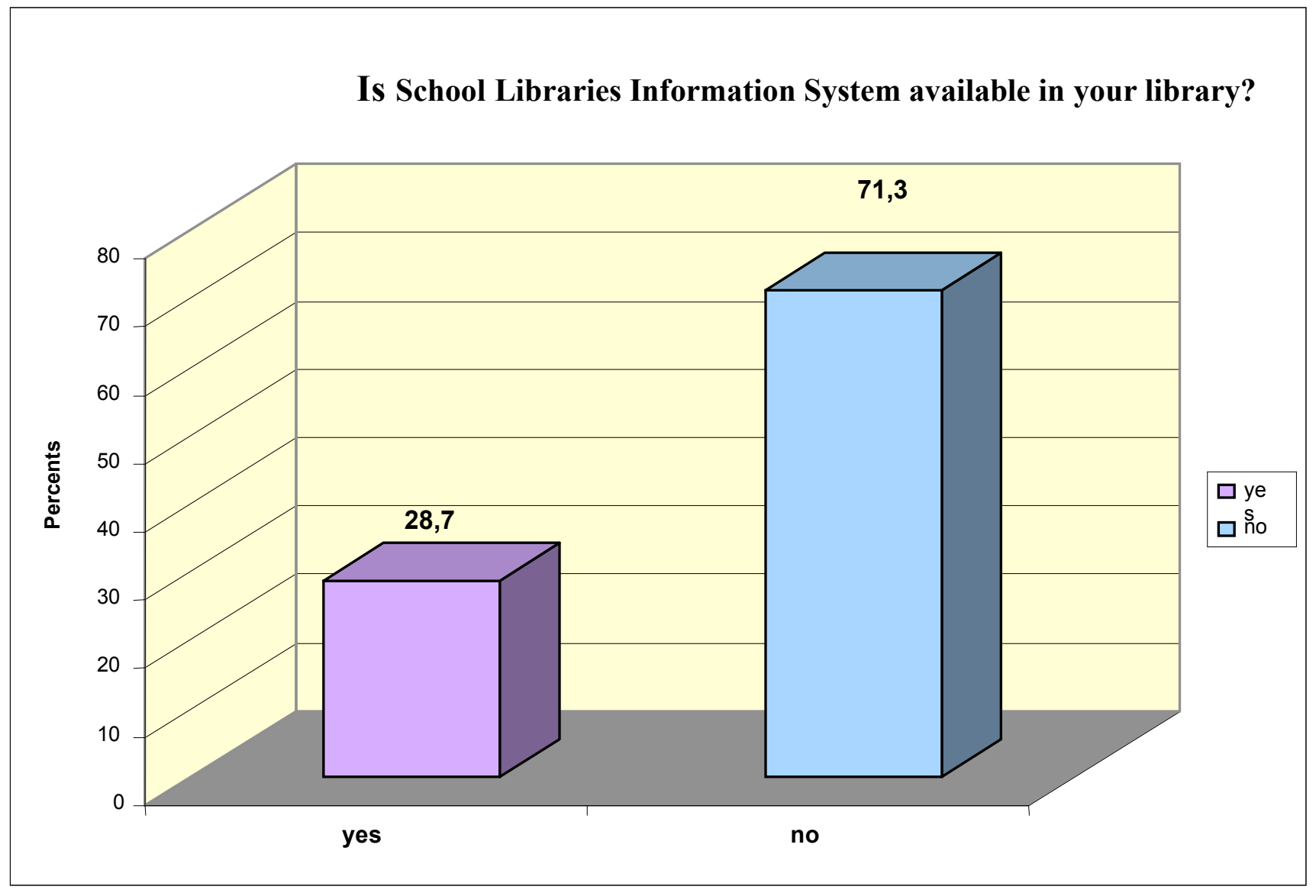




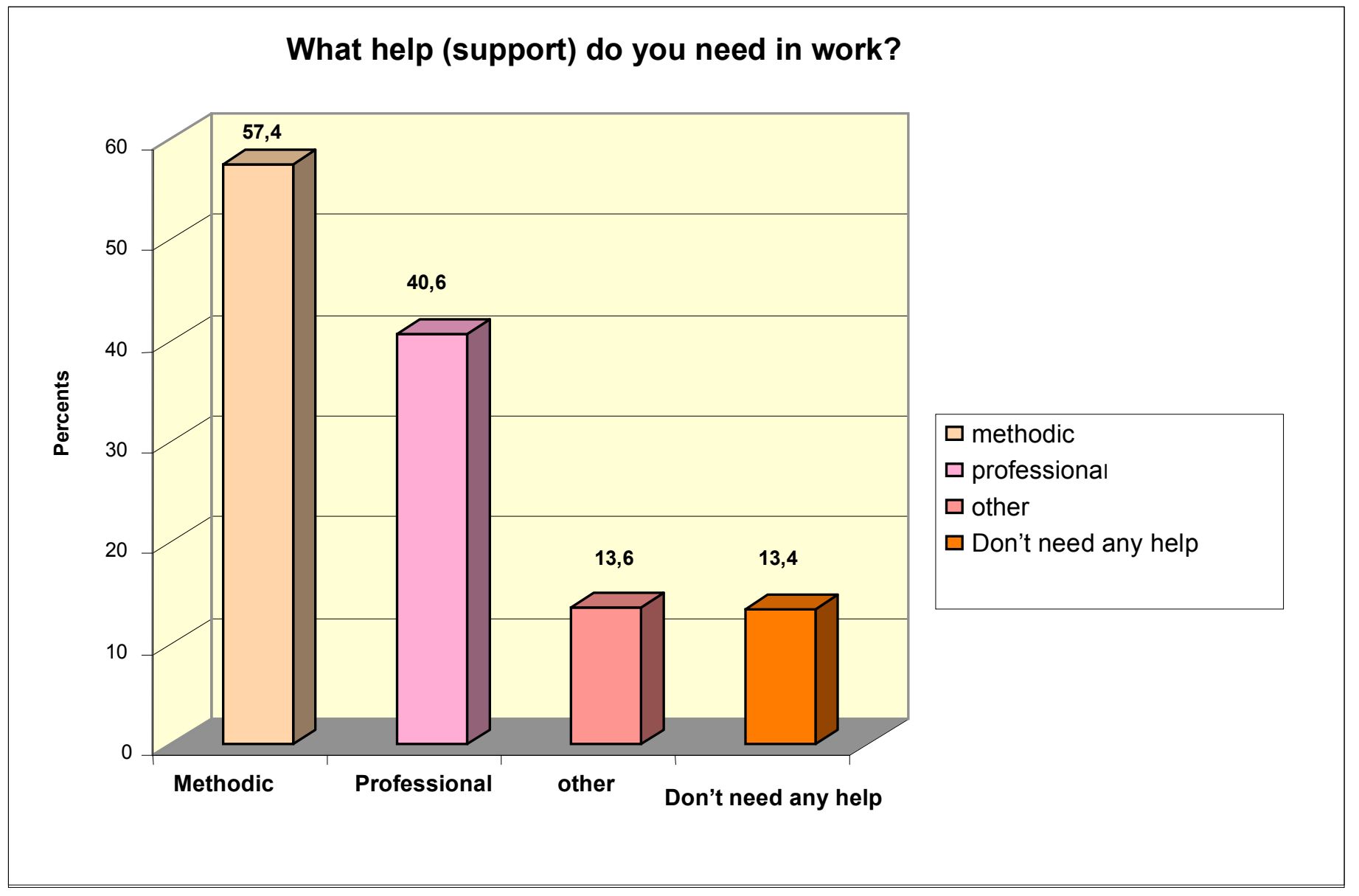

Analysis of the questionnaire shows that 243 schools do not have computers at all and only seventeen have twenty or more. $1 / 4$ (one forth) of those questioned do not have "real" librarians. Such schools use this method: I came, returned the textbook or book and left. It is characteristic of smaller schools, where teachers, having a certain number of lessons, work as librarians that are usually their second duty.

Over 40 percent of schools have only up to 300 students. Only 14 percent show, that the number of students at their schools is over 1000. The problem is that the number of the staff for school librarians was approved by the Municipality without taking into consideration the number of students and consequently the amount of work. For example, the Board of Vilnius Municipality approved only 2 staff members for a school library with a reading room. They did not take account the fact, that some libraries (especially those in big schools, where the number of students is 1000 or over 1500), have more than one reading room so two staff members are not enough. About $14 \%$ of all schools in our country have two or more reading rooms. They usually have separate reading rooms for teachers and students and one computerized reading room. There are only about $4 \%$ of secondary school libraries that have more than 2 workers. That is why there are many cases when one librarian has to look after two or more reading rooms. 14\% of school libraries do not have any reading rooms at all and the greatest number of school libraries has one reading room. 
As for librarians' education, nearly $60 \%$ of the questioned have a higher education. Such numbers are caused by the fact that many teachers having higher education work as librarians. A great part of librarians (having librarians' certificate), have high (college, not university) education and that is not bad. But about $7 \%$ of the staff working in school libraries has only a secondary education, and their specialty has nothing in common with pedagogic or librarianship. According to questionnaires 33,9\% of real librarians (having this profession) work in school libraries, 46,5\% of school librarians are teachers (797), and the rest are people having different professions: engineers, technicians operators, cooks, builders, workers of culture, florists, agriculture specialists, social workers, managers, dancers and many others.

Such things would be impossible, if only librarians having higher (university or college) education or teachers having higher education could work in school libraries. This order was confirmed in the Secondary School Libraries Regulations, but now school headmasters are allowed not to pay attention to them. I think that abolition of school library regulations caused a lot of damage for schools. We cannot expect better quality in their work without raising qualification requirements for school librarians.

The representatives of Ministry of Education and Science maintained that librarians' qualifications are not regulated by the state (as are those for a doctor or teacher. That means there are no strict requirements for the education or the necessary competence. There are many librarians without special education working in public or university libraries as well. But the situation there is better, as people without special education work together with real specialists (professionals) and they successfully gain necessary competence in quite a short time. At schools there are very few possibilities to learn, to improve, because there is often only one librarian. It is impossible to expect high quality in such cases.

Answering the question "should a librarian's duty be equal to a teacher's duty?" 46,7\% answered "yes" and 33,3 \% answered "no." Theresa had a different opinion or no opinion at all. It should be mentioned that the negative answer "no" was given by the librarians (specialists). It is normal as the problem of changing qualification has not been solved yet.

The fund of textbooks is being looked after by librarian in most schools $(96.1 \%)$. The biggest part of the questioned about the work with textbooks is not paid (76.4\%) for that. The situation should be changed as working with textbooks requires a lot of effort and responsibility: besides processing textbooks funds librarians analyze teachers' opinion on buying new textbooks, prepare purchase documents, and communicate with publishing houses and Municipality. It should be noticed that according to"Recommendation for the description school librarian's duty" (approved by the Ministry of Education and Science) working with textbooks is considered to be additional work and it should not be included in the librarian's duty description. For additional work librarians should get extra pay, the amount of which depends on the agreement between the employer and employee. This fact demonstrates that the school librarian completely depends on the headmaster: he/she prepares the job description. If the headmaster chooses, he or she can include working with textbooks in the job duties; then they do not have to pay.

$71 \%$ of those questioned had not started using computer program ISLS for school libraries' automation (Information School Library System or ISLS). By the end of the year 2006 ISLS had to be activated in all schools, but only about $30 \%$ of schools had it. The situation is really unsatisfactory. According to ISLS specification (a definition of the System introduction) school libraries had to be provided with computers and other equipment and offer consultations. Almost none of these have been done. The courses on ISLS in PPRC (Pedagogic Proficiency 
Raising Centre) are not enough to start working with the automatic system. Nobody could give the advice. This problem has not been solved in time. In our opinion, in order to solve it, school librarians' methodic centre should be established where ISLS consultants could work constantly. Now ISLS 2 (a new version of the program) has been introduced and courses on this new version are going to be organized, but the methodic centre will not be established in the nearest future.

According to the survey (diagrams), librarians need methodic and professional help most of all. They also mentioned they needed legal and financial support. Strange, but it is true, that $13.4 \%$ of the questioned librarians didn't need any help. They may not understand what they should know.

To sum up the results of the questionnaire we can state that the main problems in the school librarians' work are: the lack of methodic help, lack of literature, shortage of funds, low salary of the librarian, difficulties with the introduction of the computer library automation system (ISLS), bad working conditions, hard work with textbooks, great amounts of work, additional work, shortage of staff (especially in big schools where the number of students is not taken into consideration), overcrowded reading rooms.

Scanning the data about the age of school librarians, optimism disappears. $68 \%$ of them are over 40 years old. After older librarians' retirement we may experience the shortage of librarians, not only teachers'. Are young people going to choose a librarian's profession with such payment and such "perspectives"?

\section{Methodical help for school librarians. A Methodic Group of Librarians and its activity sample.}

The methodical help to school libraries should be given by the Municipality public libraries according to the Law of Libraries, but there are no necessary regulation acts and the help is given not very often. The National Library of Lithuania (LNL) carries out the functions of the national methodological centre. It is the main centre of methodical help for school libraries too. LNL provides methodological assistance to Lithuanian libraries on library science, bibliographic and information issues and is the co-ordination centre for national bibliography, Lithuanian publications, state registration, information, library research work and methodological activity. LNL has the Centre of, but it would be better if we had a separate National Children Library as other countries of Eastern and Central Europe have. The problem is that the librarians working in distant towns and villages can hardly reach the Centre. Methodic help for school librarians should be provided by the Municipality public libraries, and this activity should be defined in their regulations. Greater difficulties may occur only in the capital (Vilnius) where there are many schools and many school librarians. Pedagogic Proficiency Raising Centre (PPRC) organizes qualification improvement seminars for school librarians, and they have already prepared an elementary librarianship teaching program which will be used for teaching school librarians (not specialists). It will start this year. In the nearest future the LNL is going to prepare a publication about the elements of library science. Sometimes librarians conferences are organized in the country, where the most important questions are discussed, guests are invited, librarians share their work experiences.

In some towns more active and experienced librarians organize methodical groups (MG), and give seminars for those who are less experienced. It is done without any salary though school librarians are among those who are the least paid.

For example, the MG in Kaunas (the second largest city in Lithuania) be presented with its activity organization principles, directions, structure, connections etc. Such MG is 
independent, so they work only in some towns and regions. MG usually elects their leading body from several members - Methodic Board.

\section{Methodic Board's (MB) main activities:}

- $\quad$ MB prepares an activity program for a year;

- MB holds meetings once every two months;

- MB organizes methodic activities of Kaunas school librarians

- MB spreads the experience of the creative school librarians, regulates the preparation of programs for developing students information skills, and initiates the publishing of information issues;

- MB initiates programs for improving librarians' qualifications.

- MB helps the Department of Education (by Municipality) organize contests, exhibitions, festival and conferences.

- MB initiates stimulation of the librarians for their active methodic work

- MB presents their activity account at the librarians' general meeting every year

- MB meetings and recommendations are registered in the Office of the Department of Education by Municipality.

\section{Organization of activities in a methodic group (MG):}

- The activity is coordinated by the organizing specialist of the Department of Education.

- The methodologist of the Teachers Qualification Centre organizes the activity in the spheres of qualification improvement and experience spread.

- MG is supervised by the chairman who gives an account for the activities of the methodic group at the librarians' general meeting once a year.

- The activity program and the account are prepared for one school year.

- Members meet together once in three months.

- Decision are made and accepted by the majority of votes in open voting. If the number of votes for and against is the same, the chairman makes the final decision.

- Sittings are recorded, protocols are kept for 5 years and documents are kept by the secretary.

\section{The aim and the objectives of the Methodic Group:}

- The aim is to seek the growth of the librarians' professional competence and efficiency assurance in educational process.

- Objective:

- To encourage librarians' cooperation.

- To spread methodic innovations among librarians and share good experiences.

- To analyze positive changes in librarians' activities.

- To evaluate, review and probate librarians' methodic works, coordinate their spread.

- To send information to the teachers' qualification centre in Kaunas, the data base of methodic works.

- To initiate new programs for the improvement of the librarians' qualification. 
- Make suggestions for librarians, methodic groups, non-governmental organizations, educational institutions about the improvements of librarians' activities.

- To help organize town events, contests, exhibitions.

- To cooperate with the methodic groups of other subjects and the school methodic board.

- Make suggestions for the librarians' encouragement, stimulation.

Methodic group members have the following rights and duties:

- The right to make suggestions for the correction of methodic, organizational or professional activities.

- Choose activity ways and forms.

- Stop their activity without giving reasons in written form.

- Duties: They must participate in the MG activities, organize librarians' methodic activities in town and solve the activity problems of the group.

- Analyze the results and changes of librarians' activities.

- Encourage methodic professional cooperation between librarians and teachers.

- Spread pedagogical and methodic innovations, share good experiences of librarians' activities.

- Participate in the activities of the librarians' methodic group.

- Follow the rules of the librarians' methodic group.

\section{Structure of methodic group}

- Methodic group consists of 11 numbers.

- Every librarian having higher education can become a member.

- The MG is elected and approved for three years (not longer).

- The members are elected at the general meeting of librarians.

- Candidates can be offered by school headmaster, teachers, specialists of Educational Department and by the methodologists of the Teachers' qualification centre.

- The chairman (chairwoman), the assistant and the secretary are elected by the members of MG using secret voting. The membership has to be supported by $2 / 3$ of the members of MG.

\section{Methodic group communicates with:}

- The Teachers` qualification centre;

- The School methodic board;

- The groups of others subjects and education spheres.

- Associations, societies, funds, publishing houses, libraries, pedagogical-psychological service.

The Methodic Group of Kaunas School Librarians (MGKSL) is especially active in developing student's information skills. As the development of information skills is not included into the curricula (either as a compulsory or optional subject), MGKSL prepared "The program for developing information skills in 1-4 and 5-12 forms". The Program was probated by the City 
Schools' methodic group and the specialists of the Municipality Educational Department, primary school teachers and librarians of universities. Using these programs school librarians' conduct lessons on information skills. It has become a tradition to hold information literacy contests in our schools and city. The contests are organized by the Department of education. They form a working group consisting of the school librarians from secondary schools, gymnasiums, universities and teachers of the native language and information technology teachers. This working group prepares integrated theoretical and practical tasks for the contest. The theoretical part of tasks includes:

$>$ Librarian knowledge;

$>$ Surfing the Internet;

$>$ The principles of applying information.

Practical tasks are done on the computer (by the students):

$>$ Search for some information on the Internet;

$>$ Edit the material with the text editions;

$>$ Send documents by e-mail.

Such tasks give knowledge and experience, develop information culture, and stimulate creativity and independence. Sample tasks are customized for Lithuanian schools, so there is no value in demonstrating them to the international society.

During the contests students compete both individually and in teams. While working they discuss things cooperate and achieve better results. This contest method was chosen due to the fact that team work is becoming of great importance in consequence of rapid development of information and computer technologies and the increasing amount of information. Such contests are organized in two stages: first at school in April and further in the library of Kaunas Technology University (KTU) in October.

The students - winners of school contests come to the University contest. It usually takes place in KTU library where future students get familiar with the environment, funds, catalogues and service available in the library. The librarians let them use computers, reading room, funds and provide with qualified help organizing the contest. The winners of the contests are awarded prizes. Last year Methodic Group of Kaunas School Librarians (MGKSL) held a scientific-practical conference entitled "The School Library and the Society of Knowledge" for all librarians of the country. They prepared and distributed the material of the conference report. MGKSL has issued many methodic publications for school librarians.

\section{Reading promotion in Lithuanian and school libraries' participation in it.}

In 2005 in Lithuania we carried out a sociological survey, "Reading scale, trend and needs," which indicated that reading had become less popular among different age groups of people. 1/5 of the citizens do not read any newspapers or magazines at all. 2008 is scheduled to be a Year of Reading in Lithuania. The Year of Reading is one stage of the Reading Promotion Program (further RPP or Program) confirmed by the Government. This Program started in 2006 and it will be realized till 2011. The initiation of this program was caused by the fact that $34 \%$ of adults do not consider themselves to be active readers and they do not like reading at all 
(according to a November 2007 survey). So, reading promotion is really important in our modern society as reading is gradually being overshadowed by other means of getting information. Other leisure activities are becoming more and more popular among adults as well as children. Children spend more and more time watching television or playing computer games. Reading for them is a less attractive activity which requires certain skills. There is no system for the assessment of students reading skills, which could reveal the reasons of the lack of these skills.

Implementation of RPP will help to stimulate activity, encouraging people of different ages and social groups to read more, improving reading skills and raising reading prestige in the Lithuanian society. The aim of the Program is to increase the number of people reading constantly or frequently, in this way to train a creative, intellectual, critically thinking, publicspirited and responsible personality.

The main reading promotion objects of the Program and the methods to achieve them are as follows:

1. It is important to create financial conditions to realize the reading stimulation projects. It was necessary to prepare legal and funding regulations, rules of contests and other necessary acts. They were prepared and confirmed. The Program stimulates projects that popularize books, reading practice and emphasize the importance of books and reading for the knowledge of culture, personality development and self education.

2. The second important objective of the Program is to improve the skills of the people, working in sphere of culture and education to promote reading. For that purpose instructions and training are organized for people working in reading promotion projects, they are provided with good practical examples. Publishing houses, authors, educational and cultural institutions will be encouraged to prepare informative and methodic material on reading promotion for parents, teachers' and students. Moreover, reading promotion should be included into the qualification improvement programs for kindergarten teachers, social teachers and librarians.

3. The third objective is to strengthen communication and cooperation between institutions in the sphere of reading promotion, using RPP as the connection between institutions and disciplines will be strengthened, making the partnership of different sectors more active.

4. The fourth objective is a planned system for analyzing reading skills, directions and needs. Assessment tests for children's reading skills will be prepared and they will help reveal the reasons of the skills shortage and to strategies for eliminating them.

5. The fifth objective is as we have already mentioned: to propagate reading and to raise its prestige in the society. In order to fulfill that, different means will be used. One of them is the Internet website where reading promotion initiatives and projects are introduced. The website has special pages for children and the youth, where the information about books and reading is provided in an attractive way, young people are invited to discuss.

Similar reading promotion programs were carried out in different Western countries, especially in Scandinavia. Successful examples are provided by our neighboring countries, Poland and Latvia. Realizing Reading Promotion Program in Lithuania has been based on the experience of these other countries as well.

The organizers of this Program are the Ministry of Culture and the Ministry of Education. The coordinator of the program realization this year is Lithuanian National Library's Children's Literature Centre and its director Aldona Augustaitienè.

School librarians willingly take part in different state actions. Different reading projects, contests, questioning competitions, selecting of the most popular book among children and adults this year, conferences are offered. This year the state financing is given to such 
projects as "Rainstorm of reviews "and "Public reading in non-traditional spaces". Our school joined this project as well: 50 senior class students with their teachers visited the Scientists' Palace established in the ensemble of old architecture outside the city. We participated in the musical-poetic composition "Man's mystery play". The event was held to honor the 150 th anniversary of Vincas Kudirka, a famous Lithuanian poet and the author of Lithuanian National Anthem. Actresses read extracts from the poet's letters and works, played his works for the piano, and the students heard new facts of his biography. I am sure that friendship with a book, which starts at school, causes in a personality further positive attitude to reading.

For that reason the efforts of school librarian's encouraging young people to read more are very important. Personality of the librarian, his erudition, ability to communicate with young people and help to choose the best books are also very important. Many people prefer authority of a person to the effect of some impersonal event.

The Internet website, created for the Year of Reading, contains information about Reader's contest, the winners of which are promised prizes for erudition, original presentation of the books, interesting ideas how to stimulate these who do not read, for argumentative opinions about some writers and their books, for book choosing criteria. Students (younger and senior) willing to participate in this contest, have to fill in a form online and sent it to the organizers of the contest. School librarians play the role of mediator: they additionally announce this contest in schools, invite the readers of the library to participate, explain criteria of the assessment. If necessary, they explain where and how to fill in a form. School librarians also encourage students to participate in the election of the most popular books for teenagers, children and adults in the election of the Book of the Year. Also they encourage students to visit the website of the Reading year and discuss about the books, express their opinion.

Three probations abroad are financed in connection with the announced Year of Reading. I am one of those who won the contest for getting a probation grant, and for this reason I am here at this conference. I am obliged to gain Reading Promotion experience from other countries and share it with the librarians in Lithuania. Lithuanian school librarians almost have no opportunity for improvement of their qualification abroad to get experience of other countries, because of the financial problems and the problem of lack of knowledge in foreign languages.

\section{Lithuanian school libraries' perspectives and aspirations.}

School Improvement Program Plus ("SIP+") was confirmed by the Ministry of Education and Science of Lithuania in 2007-12-03. The mission of this program is to plan and help assimilate the structural funds of the European Union, the funds of projects and use them for General education in Lithuania. The Program SIP+ (further Program) will start at the end of the 2008 and last till the end of 2013.

The competence improvement of school librarians using modern equipment is a part of the SIP+. Analysis of the current situation shows that there are some advantages and disadvantages in the of our school libraries. The advantages are:

The School Libraries' Information System (SLIS) is being spread. Since 2005 year 485 school librarians were instructed how to use and spread this System.

$>$ Lithuanian school libraries are provided with quite a lot of computer techniques. According to the account "Benchmarking Access and Use of ICT in European Schools 2006", prepared by European Council in 2006 61.7\% of Lithuanian schools used 
computers for education in school libraries, whereas the average of use in the European Union is only $33.4 \%$.

The disadvantages of school libraries are:

$>$ The number of trained school librarians is not sufficient.

$>$ The spread of SLIS is too slow. More consultations are needed for those who beginning to work with the library automation program.

$>$ Bigger part of the programming and technical equipment in Lithuania is out of date.

$>$ There is no system of school librarians' qualification improvement and assessment.

$>$ The motivation of school is insufficient.

The aims and objects of the Program part "The improvement of school librarians' competence, using modern technologies".

The aims are to improve the service quality and efficiency in school libraries and to raise the competence of school librarians. In order to achieve these aims it is necessary:

To investigate and prepare the need and competence analysis.

$>$ To prepare school librarians' training programs.

$>$ To prepare technological computer literacy program.

> The program should be prepared using School Librarians' Digital Literacy Standards (SLDLS).

To prepare methodic materials for working with SLIS.

$>$ To prepare school librarians-supervisors.

$>$ To instruct school librarians on technical literacy.

$>$ To train librarians in digital literacy using SLDLS.

$>$ To instruct school librarians and train them to work with SLIS.

This state project "The improvement of school librarians' competence, using modern technologies" was prepared by PPRC (Pedagogic Proficiency Raising Centre) with its partner ITC (Information Technologies Centre). After having carried out the project it is expected that all school librarians will have equal possibilities to participate in educational activities, to improve their skills, to gain new skills and to get direct indirect help to become or to remain active participants of economic and social life.

During the project it is planed to use the experience of foreign countries and to stimulate cooperation of educational institutions in seeking optimal use of all the resources. The improvement of school librarians' competence will also help the spread of the intellectual potential of the society seeking to make knowledge and science the most important factors which would ensure well-being of the people.

The process of the project and the achieved results will be publicized to the people and organizations interested in it. They will get information about the support, about the improved accessibility to educational services and their quality. The information will be offered in:

$>$ Mass media - information reports to news agencies and mass media;

$>$ Electronic space - information reports on the websites of Ministry of Education, PPRC and ITC. 
Information publications;

$>$ During the conferences.

The good experience will be spread through educational institutions, educational service users and self - government institutions organizing educational activities in the region.

Having finished SIP+ by 2015 about 240 school libraries should be modernized. The aim of the project on modernization of libraries is to provide school libraries with necessary technical and program equipment and furniture. That would be to improve the quality of library services and to ensure better conditions both for teaching and learning.

These were the perspectives according to the carrying out of the SIP + .Finally, this paper will present school librarians' long-lasting wishes and some hopes which could be fulfilled with the help of state institutions and good will.

2. Compensation studies program will be created and approved, according to which any school librarian will be able to gain psychological - pedagogic knowledge necessary for a teacher. Teachers working as school librarians will be able to attend the compulsory librarianship primary course. Then every school librarian could feel self-confident at work and would be at the maximum useful for the school community.

3. The school librarian's duty is considered to be pedagogic, as they work directly with students.

4. Teaching program 80 - hours is being planned and realized in School Librarians Digital literacy Standard (SLDLS). School librarians having mastered this program would have the necessary qualification and gain competence.

5. Information skill development is included into the compulsory educational programs.

6. Municipality public libraries, according to Lithuanian Libraries Law, provide systematic methodic help and professional innovations to school librarians.

7. Having completed Reading Promotion program (after 2011) school librarians will be managed and serviced by the staff aware of different ways how to promote reading. Also a lot more students and teachers will come to the libraries and read.

8. By the end of the year 2008 the law on the payment for the office workers of budgetary institutions (including schools) will have been enacted which will give more freedom for employer. As a result, headmasters of big schools will be able to establish additional staff in the libraries for introducing library automation system, creating an electronic catalogue, consulting students and parents on the choice of profession and employment questions. They will also be organizing reading promotion events, carrying out various surveys, analyzing them and giving lessons on information skills development

\section{References}

1. The Law on the Changes of the Library Law in Lithuania. 2004-07-15, $\mathbf{N}_{-}^{\circ} \mathbf{I X}-2378$.

2. Reading Promotion Program confirmed by the Government of Lithuania, (2006-11-30, resolution $\mathrm{N}_{-}^{\mathbf{0}} 1200$ ).

3. School Improvement Program Plus confirmed by the Minister of Education and Science, (2007-1203, Order No ISAK-2331).

4. School Libraries Digital Literacy Standard confirmed by the Minister of Education and Science, (2002-10-25, Order N_ 1782). 
Biographical Notes I have worked at school library for 24 years. I am a teacher of Mathematics. I have been a leader of School department in Lithuania Librarian's Association for 6 years. I maintain school website and present professional development workshops and conference sessions in Lithuania elsewhere.

\section{Statement of Originality}

This statement certifies that the paper above is based upon original research undertaken by the author and that the paper was conceived and written by the author(s) alone and has not been published elsewhere. All information and ideas from others is referenced. 